\title{
The influence of ownership structure on transfer pricing
}

Wiwid Aprilianingrum Purnamasari

Alumni of Master Program in Accounting, Universitas Islam Indonesia, Yogyakarta, Indonesia wiwid.purnamasari@students.uii.ac.id 


\title{
The influence of ownership structure on transfer pricing
}

\author{
Wiwid Aprilianingrum Purnamasari
}

Alumni of Master Program in Accounting, Universitas Islam Indonesia, Yogyakarta, Indonesia

JEL Classification:
G32, M41
Keywords:
Ownership structure, transfer pricing,
tax avoidance.

*Corresponding Author:

wiwid.purnamasari@students.uii.ac.id

DOI:

10.20885/jca.vol2.iss2.art5

Copyright (C2020

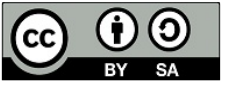

This is an open access under CC-BY-SA LICENSE

\begin{abstract}
This research is to analyze the influence of ownership structure on transfer pricing. The ownership structure in this study consisted of foreign ownership, managerial ownership, institutional ownership, concentrated ownership, and government ownership. Purposive sampling was used to collect 148 manufacturing companies listed in the Indonesian Stock Exchange between 2013 and 2017 out of 694 samples using EViews-9 and a generalized linear model. The results showed that foreign ownership and government ownership had positive effects on transfer pricing. In contrast, managerial ownership, institutional ownership, and concentrated ownership negatively affected transfer pricing.
\end{abstract}

\section{Introduction}

The transaction between taxpayers with the special relationship is generally called transfer pricing. Transfer pricing is pricing determined in the transactions between division members in a multinational company. The agreed price might not be in reference to the market price but fits the consensus between the divisions. In reality, however, the transfer pricing is used by multinational companies to avoid tax by minimizing the tax payable which leads to a loss in tax revenue (Refgia et al., 2017).

The higher the growth of a sale, the lower the tax avoidance carried out by the company, because, high sales growth indicates high profits in the company so that it can contribute to management not to do corporate tax avoidance (Faradisty et al., 2019). On the other hand, the large amount of tax payable which is incurred by a company might result in tax avoidance (Adityamurti \& Ghozali, 2017), it's for reducing the amount of tax payable. This act will cause a fine and bad reputation for a company (Jasmine \& Paulus, 2017). Tax avoidance is performed by a company as the result of the policy made by the leaders of the company (Saputra et al., 2015). Tax avoidance is defined as an attempt to reduce the amount of tax payable using the strategies which are within the taxation regulations (Dewi \& Sari, 2015).

One of the tax avoidance examples in Indonesia is that was perpetrated by multinational corporate PT Toyota Motor Manufacturing Indonesia. Referring to the findings of the Directorate General of Taxation (DGT), PT Toyota Motor Manufacturing Indonesia was alleged of doing tax avoidance in the form of transfer pricing. The findings of DGT proved that PT Toyota Motor Manufacturing reduced the number of tax payables from 2005 to 2008 based on the Annual Tax Return. Transfer pricing can occur because of several factors, one of which is the ownership structure that affects a company (Shodiq et al., 2017). The ownership can be vested to the individual investor, government, and private institution (Puspita \& Harto, 2014). 
Moreover, this study focuses on the ownership structure as an independent variable encompassing foreign ownership, managerial ownership, institutional ownership, concentrated ownership, and government ownership. This study differs from the previous studies which partially applied the ownership structure. This was carried out due to the inconsistent results of the previous studies, like those performed by Nurjanah et al. (2015), Cristea and Nguyen (2016) Kiswanto (2015), Refgia et al. (2017), Khotimah (2018), and Sukma et al. (2018).

In addition, the researcher also observed that the variables of tunneling incentive, bonus mechanism, debt covenant, good corporate governance, and company size could be the control variables over the influence of ownership structure on transfer pricing decisions. Therefore, this study is aimed at analyzing the influence of ownership structure on transfer pricing using the data collected from annual reports of 148 manufacturing companies listed in the Indonesian Stock Exchange (IDX) in the period 2013-2017 out of 694 samples taken.

\section{Literature Review}

\section{Influence of Foreign Ownership on Transfer Pricing}

Foreign ownership is the share ownership by either a foreign individual or institutional party. The greater the foreign ownership has implications for increasing financial instrument disclosure (Probohudono et al., 2019). The company whose shares are owned by a foreign party tends to face asymmetrical information dissemination due to geographical and language barriers. As a result, a company with the majority of shares owned by a foreign party will be driven to disclose and report the information voluntarily and extensively.

However, the larger the foreign share ownership, the larger the control of the foreign party to make a company decision that is profitable for the party including the policy on pricing and the amount of transfer pricing transaction (Khotimah, 2018). A dominant foreign ownership holder can effectively control the management to reach the company goal to maximize profits; on the other hand, it can be aggressive toward the tax incurred and monitoring cost reduction (Ardianingsih \& Ardiyani, 2010). This means that foreign ownership can minimize agency costs and maximize profits for the company.

A study by Kiswanto (2015) showed that foreign ownership influenced transfer pricing. Whenever a foreign party has invested with the proportion of at least $20 \%$ in a public company in Indonesia, the foreign party can have a significant influence in the company decision making process including the policy on transfer pricing involving a foreign party. This finding is supported by the research conducted by Refgia et al. (2017) which also revealed that foreign ownership affected the decision to do transfer pricing. Meanwhile, a study conducted by Nurjanah et al. (2015) explained that the decision to do transfer pricing was not solely made by foreign ownership holders, but also by other non-foreign shareholders in a company. The study result is in line with the research performed by Khotimah (2018) and Sukma et al. (2018) which assumed that foreign ownership did not influence a company's decision to do transfer pricing.

Based on the inconsistent results of the previous studies on the influence of foreign ownership on transfer pricing, the first hypothesis is formulated as follows.

$\mathbf{H}_{1}$ : Foreign ownership has a positive influence on transfer pricing.

\section{Influence of Managerial Ownership on Transfer Pricing}

Managerial ownership is a situation where managers own a company's shares. Thus, the managers are also the shareholders of the company (Kalbuana et al., 2017). Agency theory assumes that managerial ownership structure is an instrument to reduce agency conflict amidst several claims to the company. The information imbalance approach views the managerial ownership mechanism as a means to minimize information imbalance through information disclosure in the stock market. Therefore, the bigger the proportion of managerial ownership in a company, the 
more aggressive the management in realizing the interest of the shareholders, in this context is the management itself (Ardianingsih \& Ardiyani, 2010)

With a higher level of managerial ownership, a manager has a right to vote and a strong position to control a company. This can result in a defensive act where the external shareholders will have difficulty in controlling the manager's actions. Referring to a study conducted by Ardianingsih and Ardiyani (2010), managerial ownership influences the decision to do transfer pricing. Managerial ownership can help unify the interests of the shareholders and manager, consequently, the increase in the proportion of managerial ownership will improve the corporate performance. In contrast, the study conducted by Kalbuana et al. (2017) assumes that managerial ownership does not significantly influence the attempt of tax avoidance. The finding is supported by a study performed by Zahirah et al. (2017) which states that managerial ownership does not have that large opportunity and right to decide the tax policy of a company.

Based on the research findings above mentioned which highlight the inconsistency of managerial ownership influence on transfer pricing, the hypothesis is formulated as follows.

$\mathbf{H}_{2}$ : Managerial ownership has a negative influence on transfer pricing.

\section{Influence of Institutional Ownership on Transfer Pricing}

Institutional ownership is a percentage of share ownership by institutional investors like the bank, investment company, or other company and institution (Fransiska et al., 2016). According to Putri and Lautania (2016), with institutional ownership, shareholders are able to optimize the monitoring of management performance by supervising each decision made by the management as the company operations executive.

Meanwhile, the higher level of institutional ownership will create more effective supervision to reduce opportunistic managers and to monitor the company decision making process and performance. Institutional ownership has good ability and experience in business and finance. According to Dewi and Jati (2014), institutional ownership does not influence tax avoidance. The existence of institutional investors indicates the pressure from the institutional party to the company management to conduct an aggressive policy to gain maximum profit for the investors. The finding is in line with the research conducted by Maharani and Suardana (2014), Fadhilah (2014), and Dewi and Sari (2015). Nevertheless, a study performed by Cahyono et al. (2016) states that institutional ownership influences tax avoidance attempts.

Based on the inconsistency found in the research above related to the influence of institutional ownership on transfer pricing, the hypothesis formulated is as follows.

$\mathbf{H}_{3}$ : Institutional ownership has a positive influence on transfer pricing.

\section{Influence of Concentrated Ownership on Transfer Pricing}

A company ownership structure is grouped into dispersed ownership and concentrated ownership. Dispersed ownership occurs whenever the outsider equity owned by most of the investors has a relatively low value (Utthavi, 2015). Concentrated ownership tends to bring about interest conflict between controlling shareholders together with management and non-controlling shareholders (Kiswanto, 2015). The ownership concentration is highly likely to prioritize own interest which leads to entrenchment effect and sacrifices incentive alignment effect. The higher the ownership concentration leads to more control by the owners over the managers (Dewanta \& Arifin, 2020). A high level of ownership concentration will encourage the shareholders to actively monitor the managers since the decision to maximize value will significantly affect the majority shareholders. This may result in the utilization of concentrated ownership as a mechanism to reduce agency conflicts. Concentrated ownership is usually applied in countries with a low level of investor protection (Utthavi, 2015).

Concentrated ownership is about how to control and who holds the control over all or the majority of company owners as well as all or the majority of the executants of business 
activities in a company. A study by Utthavi (2015) explains that concentrated ownership was related to tax avoidance. In the countries with a weak taxation system and high rate of corruption, the improvement in investor protection causes no increase in investment when private monitoring is too expensive for the investors (Utthavi, 2015). The larger the concentrated ownership, the larger the ownership of controlling shareholders which might result in an increased possibility of tax avoidance by a company.

Based on the above-mentioned descriptions, the hypothesis is formulated as follows.

$\mathbf{H}_{4}$ : Concentrated ownership has a negative influence on transfer pricing.

\section{Influence of Government Ownership on Transfer Pricing}

Government ownership is a situation where the government is involved in a company shareholding. The government ownership structure is generally to unite the interest of the managers and that of the shareholders (Hunardy \& Tarigan, 2017). Government ownership hints at the right of the government to appoint a company director; consequently, the business decisions made are the extension of government interest. This type of company will receive more attention from the community because they have more expectations for state-owned enterprises than for private companies. The government intervention in company ownership can give more pressure to the company to disclose more information since the government is one of the bodies trusted by the people (Zulfi, 2014).

The study conducted by Dewayanto (2010) states that government ownership influences the control exercised by a company. This result contradicts the research of Inanda et al. (2018) which urges that the majority of ownership by individual, family, institution, government, and the foreign party does not influence tax avoidance decision. The finding concords with the research finding of Lubis and Yusralaini (2015) mentioning that there are only a few companies with government ownership inside their ownership structure.

Referring to the discussion above relating to the inconsistency of findings on the influence of government ownership on transfer pricing, the hypothesis is proposed as follows. $\mathbf{H}_{5}$ : Government ownership has a positive influence on transfer pricing.

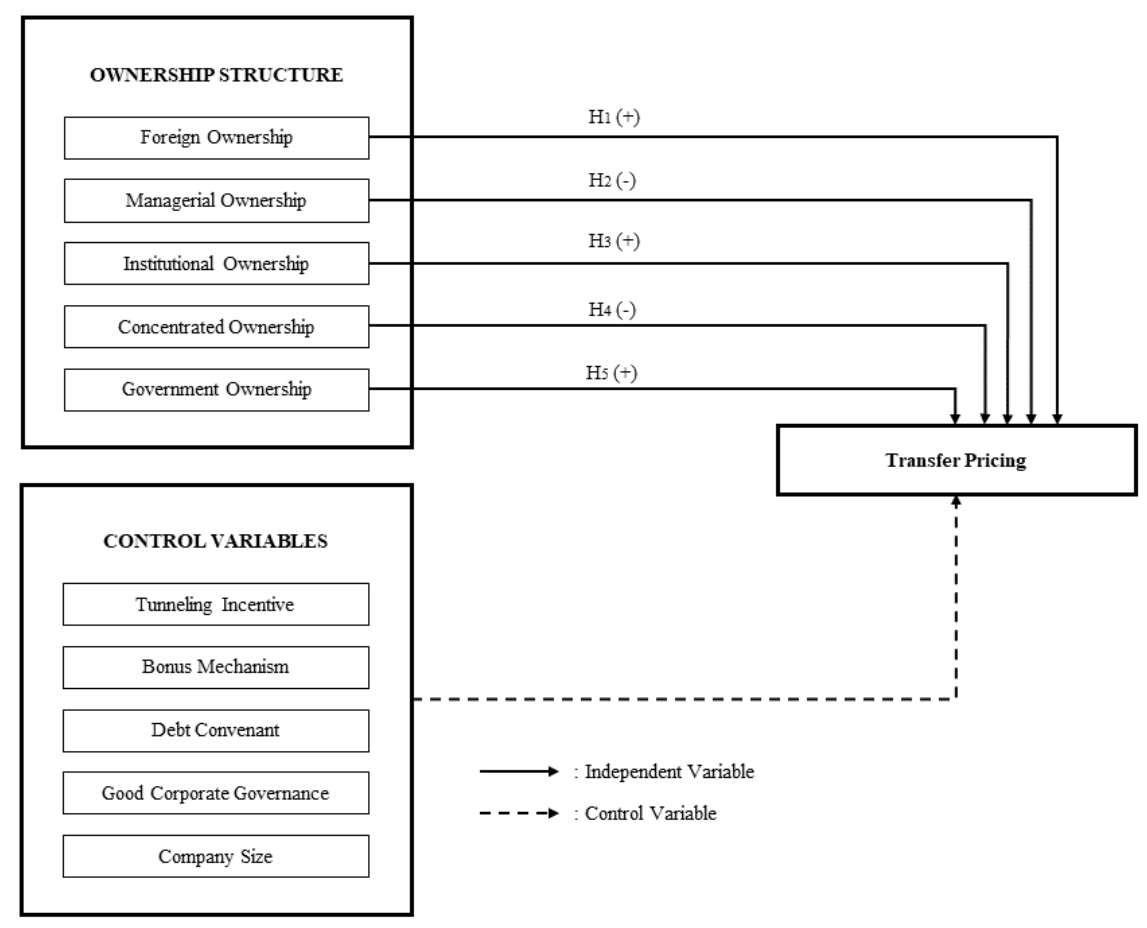

Figure 1. Research Model 


\section{Research Method}

This study collected the data from the companies' notes and documents. The data used in this study were secondary data collected from the Indonesian Stock Exchange through its website at www.idx.co.id. Using the purposive sampling method, the samples were sorted from the companies listed in the Indonesian Stock Exchange which published their audited annual financial statements in the period 2013-2017. The annual financial statements presented the data which involved foreign ownership, managerial ownership, institutional ownership, concentrated ownership, and government ownership. The number of samples in this study was 694 companies with the total data for five years.

This study includes five independent variables, namely foreign ownership, managerial ownership, institutional ownership, concentrated ownership, and government ownership. In addition, the dependent variable of this study was transfer pricing with five control variables, namely tunneling incentive, bonus mechanism, debt covenant, good corporate governance, and company size.

Moreover, Generalized Linear Model (GLM) was used to analyze the data and to avoid extreme data, classical assumptions, and outliers with the equation as follows.

$\mathrm{Y}=\alpha+\beta 1 \mathrm{X} 1+\beta 2 \mathrm{X} 2+\beta 3 \mathrm{X} 3+\beta 4 \mathrm{X} 4+\beta 5 \mathrm{X} 5+\beta 6 \mathrm{X} 6+\beta 7 \mathrm{X} 7+\beta 8 \mathrm{X} 8+\beta 9 \mathrm{X} 9+\beta 10 \mathrm{X} 10+\varepsilon$ where:

$\mathrm{Y}=$ Transfer pricing

$\alpha=$ Constant

$\beta=$ Regression coefficient

$\mathrm{X} 1=$ Foreign ownership

$\mathrm{X} 2$ = Managerial ownership

$\mathrm{X} 3$ = Institutional ownership

$\mathrm{X} 4$ = Concentrated ownership

$\mathrm{X} 5=$ Government ownership

$\mathrm{X} 6=$ Tunneling incentive

$\mathrm{X} 7=$ Bonus mechanism

$\mathrm{X} 8=$ Debt covenant

$\mathrm{X} 9=$ Good Corporate Governance

$\mathrm{X} 10=$ Company size

$\varepsilon \quad=$ Error

\section{Result and Discussion}

\section{Descriptive Analysis Results}

Descriptive statistical analysis is used to explain data descriptively. The results of descriptive statistical analysis on transfer pricing (TP), foreign ownership (ASG), managerial ownership (MAN), institutional ownership (INS), concentrated ownership (KON), government ownership (PEM), tunneling incentive (TI), bonus mechanism (MEK), debt covenant (DBT), good corporate governance (GCG), and company size (UKR) can be seen in Table 1.

Based on the results of the descriptive analysis above, it can be concluded; Mean of the transfer pricing (TP) variable in this study sample was 0.15781 or $15.78 \%$ with a standard deviation of 0.7225 . The standard deviation value which was larger than the mean indicates that the data used were heterogeneous or dispersed. The median of transfer pricing (TP) was 0.0109 . And mean of foreign ownership (ASG) variable in this study sample was 0.2654 or $26.54 \%$ with a standard deviation of 0.3289 . The standard deviation value which was larger than the mean indicates that the data used were heterogeneous or dispersed. The median of foreign ownership (ASG) was 0.0000 , with a maximum value of 0.9632 . 
Table 1. Descriptive Analysis Results

\begin{tabular}{ccrrrrrrr}
\hline Variable & $\mathrm{N}$ & \multicolumn{1}{c}{ Mean } & \multicolumn{1}{c}{ Median } & \multicolumn{1}{c}{ Maximum } & \multicolumn{1}{c}{ Minimum } & Std. Dev. & Skewness & \multicolumn{1}{c}{ Kurtosis } \\
\hline TP & 694 & 0.1578 & 0.0109 & 9.6276 & -8.6856 & 0.7225 & -1.4005 & 106.5860 \\
ASG & 694 & 0.2654 & 0.0000 & 0.9632 & 0.0000 & 0.3289 & 0.7816 & 2.0708 \\
MAN & 694 & 0.0632 & 0.0000 & 0.8750 & 0.0000 & 0.1546 & 3.3472 & 14.79430 \\
INS & 694 & 0.6696 & 0.6581 & 1.0000 & 0.0000 & 0.6577 & 8.2529 & 92.2158 \\
KON & 694 & 0.4324 & 0.4310 & 0.9800 & 0.0000 & 0.2791 & 0.0732 & 2.0841 \\
PEM & 694 & 0.0206 & 0.0000 & 0.8066 & 0.0000 & 0.1182 & 5.8042 & 35.7084 \\
TI & 694 & 0.4316 & 0.4294 & 0.9800 & 0.0000 & 0.2795 & 0.0761 & 2.0802 \\
MEK & 694 & 0.3924 & 0.9106 & 56.1020 & -334.2700 & 13.9628 & -19.8410 & 479.6160 \\
DBT & 694 & 1.1162 & 0.7588 & 39.4860 & -17.8900 & 2.7382 & 2.6367 & 72.5640 \\
GCG & 694 & 0.4008 & 0.3333 & 0.8000 & 0.1666 & 0.1102 & 0.8214 & 4.4327 \\
UKR & 694 & 18.0900 & 15.6510 & 30.4410 & 8.9422 & 5.9072 & 0.8278 & 2.0662 \\
\hline
\end{tabular}

Source: Output EViews9, 2019.

\section{Correlation Test Results}

Correlation analysis was applied to show the correlations or relations among the variables, namely transfer pricing (TP), foreign ownership (ASG), managerial ownership (MAN), institutional ownership (INSbe chec), concentrated ownership (KON), government ownership (PEM), tunneling incentive (TI), bonus mechanism (MEK), debt covenant (DBT), good corporate governance (GCG), and company size (UKR).

Table 2. Correlation Test Results

\begin{tabular}{|c|c|c|c|c|c|c|c|c|c|c|c|}
\hline & TP & ASG & MAN & INS & $\mathrm{KON}$ & PEM & TI & MEK & DBT & GCG & UKR \\
\hline TP & 1 & & & & & & & & & & \\
\hline ASG & 0.0553 & 1 & & & & & & & & & \\
\hline MAN & -0.0178 & -0.1746 & 1 & & & & & & & & \\
\hline INS & 0.0637 & 0.2267 & -0.1219 & 1 & & & & & & & \\
\hline $\mathrm{KON}$ & 0.0549 & 0.2054 & 0.0106 & 0.1520 & 1 & & & & & & \\
\hline PEM & -0.0084 & -0.1307 & -0.0715 & -0.1345 & 0.1620 & 1 & & & & & \\
\hline TI & 0.0555 & 0.2024 & 0.0078 & 0.1522 & 0.9970 & 0.1623 & 1 & & & & \\
\hline MEK & 0.0085 & -0.0427 & 0.0063 & -0.0248 & -0.0381 & 0.0086 & -0.0383 & 1 & & & \\
\hline DBT & -0.0347 & 0.0160 & 0.0934 & -0.0382 & 0.0178 & -0.0036 & 0.0175 & -0.0162 & 1 & & \\
\hline GCG & -0.0953 & 0.0796 & -0.0452 & 0.0413 & -0.0037 & -0.1194 & -0.0063 & 0.0038 & 0.0065 & 1 & \\
\hline UKR & 0.1067 & -0.1682 & 0.0265 & -0.0139 & -0.0149 & -0.0798 & -0.0188 & -0.0380 & -0.0529 & -0.0582 & 1 \\
\hline
\end{tabular}

Source: EViews9, 2019.

Referring to the results of the correlation test in Table 2, it can be concluded that transfer pricing (TP) as a dependent variable has a positive correlation with several other variables, such as with ASG amounting 0.0553, with INS as much as 0.0637 , with KON as much as 0.5499 , with TI amounting 0.0555, with MEK as much as 0.0085, and with UKR as much as 0.1067. However, with some variables, namely MAN, PEM, DBT, and GCG, transfer pricing has a negative correlation amounting to $-0.0178,-0.0084,-0.0347$, and GCG -0.0953 respectively.

\section{Generalized Linear Model Analysis Results}

This study used the Generalized Linear Model (GLM) as a statistical tool to test the hypotheses. The results are shown in Table 3. 
Table 3. Hypotheses Testing Results

\begin{tabular}{lrrrl}
\hline \multicolumn{1}{c}{ Hypotheses } & Coefficient & z-Statistic & Prob. & Results \\
\hline ASG $\rightarrow$ TP & 2.2068 & 14.8964 & 0.0000 & Accepted \\
MAN $\rightarrow$ TP & -2.2521 & -4.2535 & 0.0000 & Accepted \\
INS $\rightarrow$ TP & -0.6406 & -4.3493 & 0.0000 & Unaccepted \\
KON $\rightarrow$ TP & 1.0883 & 0.0038 & 0.9969 & Unaccepted \\
PEM $\rightarrow$ TP & 1.9929 & 0.1366 & 0.8913 & Unaccepted \\
\hline
\end{tabular}

Source: EViews9, 2019

\section{Influence of Foreign Ownership on Transfer Pricing}

Based on the testing results, it can be concluded that the first hypothesis (H1) is supported, where foreign ownership (ASG) positively influences transfer pricing, with coefficient value $2.2068\left(\beta_{1}>0\right)$ and p-value 0.0000 which is smaller than $0.05(<\alpha=0.05)$. Hence, the bigger the foreign ownership in a company, the more significant positive its influence on transfer pricing. Based on Agency Theory, this situation will rise an agency problem in which there is a disparity between principal and agent when one party (principal) hires another party (agent) by giving an authority to run the company operations. Consequently, the larger the stocks invested by a foreign party in a company, the bigger the party's influence to determine the company's policy because when an investor invests in a company, the investor expects the company can provide a rate of return by the investor's expectations. In conclusion, a foreign company that invests more than $20 \%$ in a national company will have a significantly positive influence on the company decision including transfer pricing which involves foreign parties.

\section{Influence of Managerial Ownership on Transfer Pricing}

Based on the testing results, it can be concluded that the second hypothesis is supported in which managerial ownership (MAN) has a negative influence on transfer pricing, with the coefficient value $-2.2521\left(\beta_{2}<0\right)$ and $\mathrm{p}$-value $0,000<0.05(<\alpha=0.05)$. It can be defined that managerial ownership significantly negatively influences transfer pricing. Managerial ownership in a company is assumed to be able to synchronize the disparity between the outside stockholders and the management. Thus, it can be assumed that the problems are diminished when the manager is also the owner of a company. With managerial ownership, managers are motivated to improve the company performance and tend to be more careful in making a decision since it will also affect their career. Therefore, the managers will put their maximum effort to realize the company's prosperity. The increasing number of stocks owned by the management will reduce the tendency to do transfer pricing. This is because management ownership will make the managers consider every decision made including taxation in order not to jeopardize the company's sustainability.

\section{Influence of Institutional Ownership on Transfer Pricing}

Referring to the test results, it can be concluded that the third hypothesis is not supported. Institutional ownership (INS) negatively influences transfer pricing with the coefficient value $0.6406\left(\beta_{3}<0\right)$ and $\mathrm{p}$-value $0,000<0.05(<\alpha=0.05)$. Hence, the higher rate of institutional ownership will negatively influence transfer pricing. This is because the bigger institutional ownership will increase effective monitoring to reduce the number of opportunistic managers, as well as to supervise the decision making process and company performance. The existence of institutional ownership indicates pressure from the institutional party to company management which intends to do tax avoidance to gain more profits for institutional investors. Additionally, institutional ownership aims at maximizing the company's profits, so any activity which causes loss to the company will be avoided including tax avoidance if this act is profitable for the company and the welfare of the institutional ownership holders. In conclusion, the level of institutional ownership will not affect tax avoidance. 


\section{Influence of Concentrated Ownership on Transfer Pricing}

As seen in the test results, it can be concluded that the fourth hypothesis is not supported. It means that concentrated ownership (KON) positively influences transfer pricing, with coefficient value $1.0883\left(\beta_{4}>0\right)$ and $p$-value $0.9969>0.05(>\alpha=0.05)$. Thus, the higher the concentrated ownership, the higher the proportion of control on transfer pricing. Concentrated ownership describes who and how to control the majority of the company's business activities. Through the transfer pricing mechanism, controlling shareholders can have a particular impact on the management policies, and they can even relish the tax benefits themselves. Therefore, controlling shareholders can conduct expropriation, namely by regulating company transactions and transferring tax benefits to other companies owned by controlling shareholders without regard to the interests of non-controlling shareholders. The results of this study are in line with research conducted by Timothy (2010), which stated that the higher the percentage of shareholders, the more significant the proportion of company policy and has a more significant influence so that it can be confident that the policy can benefit shareholders controlling and choosing aggressive tax policies through the practice of transfer pricing.

\section{Influence of Government Ownership on Transfer Pricing}

Based on the results of the test, it can be concluded that the fifth hypothesis is not supported, which means that government ownership (PEM) negatively influences transfer pricing with coefficient value $1.9929\left(\beta_{5}>0\right)$ and p-value $0.8913>0.05(>\alpha=0.05)$. It can be defined that government ownership significantly negatively influences transfer pricing. The bigger the government ownership, the more negative influence on transfer pricing. Government ownership is a situation where the government is involved in a company shareholding. The government ownership structure is generally to unite the interest of the managers and that of the shareholders (Hunardy \& Tarigan, 2017). Government ownership hints at the right of the government to appoint a company director; consequently, the business decisions made are the extension of government interest. This type of company will receive more attention from the community because they have more expectations for state-owned enterprises than for private companies. The government intervention in company ownership can give more pressure to the company to disclose more information since the government is one of the bodies trusted by the people ( $\mathrm{Zulfi}$, 2014). The results of this study are in line with research conducted by Inanda et al. (2018), which mentioned that the majority of ownership by individual, family, institution, government, and the foreign party does not influence tax avoidance decision.

\section{Conclusion}

Regarding the analysis results and discussion, it can be concluded that foreign ownership and managerial ownership have a positive influence on transfer pricing. In the case that foreign parties and the managerial invest in a company with a percentage of more than $20 \%$, the company decision making can be intervened by the parties, including the decision on transfer pricing. Meanwhile, institutional ownership, concentrated ownership, and government ownership have negative influences on transfer pricing. This might be due to the assumption that government intervention in company ownership can give more pressure to the company to disclose more information since the government is one of the bodies trusted by the people. Then, the existence of institutional ownership indicates pressure from the institutional party to company management which intends to do tax avoidance to gain more profits for institutional investors. Additionally, institutional ownership aims at maximizing the company's profits, so any activity which causes loss to the company will be avoided including tax avoidance if this act is profitable for the company and the welfare of the institutional ownership holders. 
The results of this study also answer the problems of the previous study which showed the inconsistency in the relationship between ownership structure and transfer pricing. This study also takes the suggestions and weaknesses of the previous research which partially examined the ownership structure variables. Therefore, this study focused on five variables of ownership structures and described the influence level of ownership structures on transfer pricing performed by manufacturing companies listed in the Indonesian Stock Exchange between 2013 and 2017.

This research was limited by the data used, namely secondary data on the influence of five ownership structures as the independent variable. The addition of other independent variables with the inconsistent result in the previous research, such as leverage and exchange rate is recommended. Besides, further research can also add the proxies of ownership structures like public ownership and family ownership to give a more detailed description of the ownership structures of Indonesian companies.

\section{References}

Adityamurti, E., \& Ghozali, I. (2017). Pengaruh penghindaran pajak dan biaya agensi terhadap nilai perusahaan. Diponegoro Journal of Accounting, 6(3), 124-135.

Ardianingsih, A., \& Ardiyani, K. (2010). Analisis pengaruh struktur kepemilikan terrhadap kinerja perusahaan. Jurnal Ilmu Pengetahuan Dan Teknologi, 19(2), 97-109.

Cahyono, D. D., Andini, R., \& Raharjo, K. (2016). Pengaruh komite audit, kepemilikan institusional, dewan komisaris, ukuran perusahaan (size), leverage (DER) dan profitabilitas (ROA) terhadap tindakan penghindaran pajak (tax avoidance) pada perusahaan perbankan yang listing BEI periode tahun 2011-2013. Jurnal Ilmiah Mahasiswa S1 Akuntansi Universitas Pandanaran, 2(2), 1-10.

Cristea, A. D., \& Nguyen, D. X. (2016). Transfer pricing by multinational firms: New evidence from foreign firm ownerships. American Economic Journal: Economic Policy, 8(3), 170-202.

Dewanta, A. F., \& Arifin, J. (2020). Corporate risk-taking behaviour: Corporate governance perspective. Journal of Contemporary Accounting, 2(1), 1-12. https://doi.org/10.20885/jca.vol2.iss1.art1

Dewayanto, T. (2010). Pengaruh mekanisme good corporate governanace terhadap kinerja perbankan nasional. Fokus Ekonomi, 5(2), 104-123.

Dewi, G. A. P., \& Sari, M. M. R. (2015). Pengaruh insentif eksekutif, corporate risk, corporate governance pada tax avoidance. E-Jurnal Akuntansi Universitas Udayana, 13(1), 50-67.

Dewi, N. N., \& Jati, I. ketut. (2014). Pengaruh karakter eksekutif, karakteristik perusahaan, dan dimensi tata kelola perusahaan yang baik pada tax avoidance di Bursa Efek Indonesia. EJurnal Akuntansi, 6(2), 249-260.

Fadhilah, R. (2014). Pengaruh good corporate governance terhadap tax avoidance (studi empiris pada perusahaan manufaktur yang terdaftar di BEI 2009-2011). Jurnal Akuntansi, 2(1), 1 25.

Faradisty, A., Hariyani, E., \& Wiguna, M. (2019). The effect of corporate social responsibility, profitability, independent commissioners, sales growth and capital intensity on tax avoidance. Journal of Contemporary Accounting, 1(3), 153-160. https://doi.org/10.20885/jca.vol1.iss3.art3

Fransiska, Y., Susilawati, R. A. E., \& Purwanto, N. (2016). Pengaruh kepemilikan institusional, kepemilikan manajerial dan kebijakan dividen terhadap kebijakan hutang pada perusahaan 
manufaktur yang terdaftar di Bursa Efek Indonesia tahun 2012-2014. Jurnal Riset Mahasiswa Akuntansi Unikama, 4(1), 1-15.

Hunardy, N., \& Tarigan, J. (2017). Pengaruh kepemilikan pemerintah terhadap kinerja keuangan melalui dewan komisaris independen sebagai variabel intervening. Business Accounting Review, 5(2), 601-612.

Inanda, T. U., Suranta, E., \& Midiastuty, P. P. (2018). Pengaruh penghindaran pajak terhadap nilai perusahaan yang dimoderasi oleh corporate governance dan kepemilikan mayoritas. Jurnal Akuntansi, 12(2), 126-145.

Jasmine, U., \& Paulus, Z. dan S. (2017). Pengaruh leverage, kepemilikan institusional, ukuran perusahaan, dan profitabilitas terhadap penghindaran pajak. Jurnal Online Mahasiswa Fakultas Ekonomi, 4(1), 1786-1800.

Kalbuana, N., Purwanti, T., \& Agustin, N. H. (2017). Pengaruh kepemilikan manajerial, beban pajak tangguhan dan tingkat pajak efektif terhadap penghindaran pajak di Indonesia. Magistra, 100(19), 26-35.

Khotimah, S. K. (2018). Pengaruh beban pajak, tunneling incentive dan ukuran perusahaan terhadap keputusan perusahaan dalam melakukan transfer pricing (studi empiris pada perusahaan multinasional yang listing di BEI tahun 2013 - 2017). Jurnal Ekobis Dewantara, 1(12), 123-138.

Kiswanto, N. (2015). Pengaruh pajak, kepemilikan asing dan ukuran perusahaan terhadap transfer pricing pada perusahaan manufaktur di Bursa Efek Indonesia tahun 2010- 2013. Jurnal Ekonomi Akuntansi, 1-15.

Lubis, E. M., \& Yusralaini. (2015). Pengaruh set kesepakatan investasi, profitabilitas, kepemilikan pemrintah, dan fasilitas perpajakan terhadap tarif pajak efektif perusahaan yang terdaftar pada Kompas 100. Jurnal Online Mahasiswa Fakultas Ekonomi, 2(2), 1-14.

Maharani, I. G. A. C., \& Suardana, K. A. (2014). Pengaruh corporate governance, profitabilitas, dan karakteristik eksekutif pada tax avoidance perusahaan manufaktur. E-Jurnal Akuntansi, 9(2), 525-539.

Nurjanah, I., Isnawati, \& Sondakh, A. G. (2015). Faktor determinan keputusan perusahaan melakukan transfer pricing. Simposium Nasional Akuntansi XIX.

Probohudono, A. N., Sugiharto, B., \& Arifah, S. (2019). The Influence of corporate governance, audit quality, and ownership, on financial instrument disclosure in Indonesia. Journal of Contemporary Accounting, 1(3), 173-187. https://doi.org/10.20885/jca.vol1.iss3.art5

Puspita, S. R., \& Harto, P. (2014). Pengaruh tata kelola perusahaan terhadap penghidaran pajak. Diponegoro Journal of Accounting, 3(2), 1077-1089.

Putri, C. L., \& Lautania, M. F. (2016). Pengaruh capital intensity ratio, inventory intensity ratio, ownership structure dan profitability terhadap effective tax rate (ETR). Jurnal Ilmiah Mahasiswa Ekonomi Akuntansi, 1(1), 101-119.

Refgia, T., Ratnawati, V., \& Rusli. (2017). Pengaruh pajak, mekanisme bonus, ukuran perusahaan, kepemilikan asing, dan tunneling incentive terhadap transfer pricing (perusahaan sektor industri dasar dan kimia yang listing di Bursa Efek Indonesia tahun 2011-2014). Jurnal Online Mahasiswa Fakultas Ekonomi, 4(1), 543-555.

Saputra, M. F., Rifa, D., \& Rahmawati, N. (2015). pengaruh corporate governance, profitabilitas dan karakter eksekutif terhadap tax avoidance pada perusahaan yang terdaftar di Bursa Efek Indonesia. Jurnal Akuntansi \& Auditing Indonesia, 19(1), 1-12. 
Shodiq, J., Widjajanti, K., \& Rusdianti, E. (2017). Determinan keputusan transfer pricing (studi pada perusahaan manufaktur yang terdaftar di BEI tahun 2011 - 2014 ). Jurnal Riset Ekonomi Dan Bisnis, 10(2), 85-105.

Sukma, S. A., Ratnawati, V., \& Natariasari, R. (2018). Pengaruh tarif pajak, tunelling incentive, mekanisme bonus, dan kepemilikan asing terhadap transfer pricing (studi empiris perusahaan yang terdaftar di Bursa Efek Indonesia pada tahun 2014-2016). Jurnal Online Mahasiswa Fakultas Ekonomi, 1(1).

Timothy, Y. C. K. (2010). Effects of corporate governance on tax aggressiveness. Hong Kong Baptist University.

Utthavi, H. (2015). Kepemilikan terkonsentrasi dan tax avoidance perusahaan yang terdaftar di Bursa Efek Indonesia. Jurnal Bisnis Dan Kewirausahaan, 11(3), 213-220.

Zahirah, A., Nurazlina, N., \& Rusli, R. (2017). Pengaruh leverage, kepemilikan institusional, kepemilikan manajerial dan ukuran perusahaan terhadap penghindaran pajak (studi pada perusahaan manufaktur yang terdaftar di BEI periode 2013-2015). Jurnal Online Mahasiswa Fakultas Ekonomi, 4(1), 3543-3556.

Zulfi, N. (2014). Pengaruh kepemilikan saham pemerintah, tipe industri, ukuran perusahaan dan profitabilitas terhadap pengungkapan corporate social responsibility pada perusahaan gopublic di Indonesia (studi empiris perusahaan yang terdaftar di bei tahun 2008-2012). Jurnal Akuntansi, 2(3), 1-28. 